\title{
Challenges in Ensuring the Rights of Vietnamese Migrant Workers in the Globalization Context - The Two Sides of the Development Process
}

\author{
Nguyen Thi Hong Yen*
}

In the current context of globalization, international migration is becoming a big issue that no nation alone can resolve on its own. It is attracting most countries' attention ${ }^{1}$ due to its impacts on national socio-economic development and political stability.

The International Organization for Migration (IOM) estimates that there were approximately 214 million international migrants in mid-2010, compared to approximately 195 million five years earlier. It naturally excludes internal migration, which represents a higher figure. According to IOM, there will be around 405 million international migrants by 2050 (IOM, 2010). Political unrest, socio-economic instability, wars, natural disasters, and economic factors (such as low income, poverty, and the lack of employment opportunities and livelihood options) are the main motivating factors in making migration decisions. Inherent disparities in living standards, opportunities for well-paid employment and income within the country, and inequalities between rich and poor countries have motivated migrants to look for new, even temporary, opportunities abroad. "Migration for economic reasons is particularly prevalent, partly due to globalization". ${ }^{2}$

According to Vietnam Migration Profile 2016, the number of Vietnamese migrating to other countries is increasing for various reasons, of which, worker migration is one of the main reasons, and it is creating many challenges both for the Government and the migrants, as well as for their families. Vietnam joined the international labor market later than other countries in the region. Only from 2000 did the process strongly occur in host countries such as

* Lecturer \& Researcher, Head of Public International Law Division, Hanoi Law University (HLU). Hanoi, Vietnam; Orcid iD: oooo-ooo3-2703-2363 at https://orcid.org/oooo-ooo3 $-2703-2363$.

1 Consular Dep't, Ministry of Foreign Affairs of Viet Nam, Review of Vietnamese Migration Abroad Migration Abroad 9 (2012), https:/eeas.europa.eu/ archives/delegations/vietnam/documents/eu_vietnam/vn_migration_abroad_en.pdf.

2 Id. at 9 . 


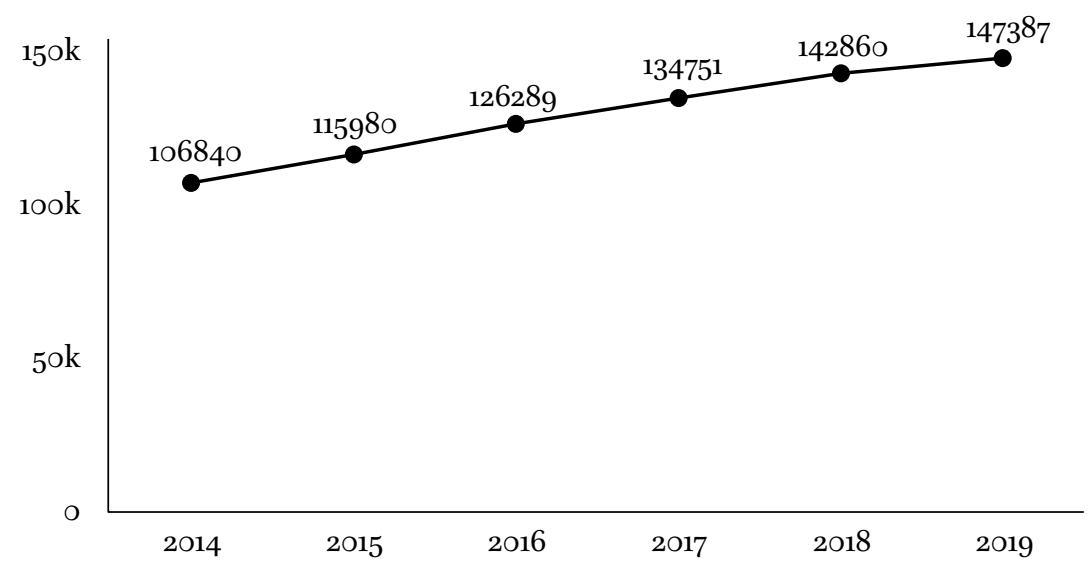

FIGURE 1 Number of Vietnamese workers abroad during the six years from 2014-2019 Note: Kim Anh, VN sends 147,387 Workers Abroad in 2019, Socialist Republic Viet. Online Newspaper Gov't (Jan. 2, 2020), http://news .chinhphu.vn/Home/VN-sends-147387-workers-abroad-in-2019/20201/38424 .vgp.

Japan, Korea, China (Taiwan), Malaysia, North Africa, and the Middle East. ${ }^{3}$ According to the latest report from the Ministry of Labor, Invalids and Social Affairs (MOLISA), there are currently 500,000 Vietnamese workers working in 40 countries and territories around the world with about 30 different occupations and sectors ranging from simple labor to technical work such as garments, electronics, domestic workers, nursing, and ship crew. ${ }^{4}$

According to migration data globally from the Population Division of the Department of Economic and Social Affairs (the United Nations) in 2019, the number of Vietnamese workers migrating abroad steadily increased from 28,100 to 76,100 over the past three decades, accounting for $0.1 \%$ of the number of migrants in the world. The number of female migrant workers accounted for nearly a quarter of the total number of migrant workers. ${ }^{5}$ In $2018,142,86$ o Vietnamese workers were working abroad. ${ }^{6}$ In 2019 , this number increased by 8,200 people to 152,53 o workers working abroad, of which female

3 Id. at $15^{-17}$.

4 Id.

5 InternationalMigrantStock2o1g:CountryProfiles-VietNam,U.N. DeP'T Econ. \& Soc. AfFS., https://www.un.org/en/development/desa/population/migration/data/estimates2/country profiles.asp (last visited July 23, 2020).

6 Kim Anh, VN Sends 147,387 Workers Abroad in 2019, Socialist Republic Viet. Online NEWSPAPER Gov'T (Jan.2,2O2O), http://news.chinhphu.vn/Home/VN-sends-147387-workers -abroad-in-2019/20201/38424.vgp. 
workers accounted for approximately one-third of the total number of migrant workers $\left(35.9 \%\right.$ female). ${ }^{7}$ Unfortunately, this data only shows the number of workers migrating through legal routes and does not include those migrating through non-traditional/illegal routes.

Many studies in the world and Vietnam have shown that labor migration mostly occurs due to economic reasons. The demand for labor and services overseas, coupled with income and living standard disparities between Vietnam and other countries in the region, has urged Vietnamese to migrate abroad. This trend has been reinforced by developments in information and communication technologies, as well as cheaper and more available international travel services, all of which allow people to contact each other, change jobs and travel more easily than ever before. ${ }^{8}$ Migrants want to find better jobs with higher income compared to what they have in their home countries. ${ }^{9}$ Also, according to MOLISA, Vietnamese workers' income is relatively stable and can be 2-3 times higher than the domestic income of the same profession and skill. ${ }^{10}$ However, most Vietnamese migrant workers abroad are unskilled workers working in low-skilled occupations. Most of them come from rural areas with poor language capabilities and low skills. Therefore, they have limited career options.

Vietnamese migrant workers are one of the vulnerable groups. They have high risks of physical and mental abuse and have to face many challenges throughout the whole migration process to work abroad. When working abroad, Vietnamese workers have to encounter social stigma and discriminatory attitudes towards foreign workers and face difficulties in accessing legal remedies. They are sometimes exploited, beaten, and mistreated, especially the Vietnamese working unofficially, or by illegal migration, or by overstaying after the legal migration contract has expired. According to IOM, illegal migrants often do not have adequate living conditions and are physically or mentally abused, isolated, exploited, robbed, and even killed by criminal gangs or traffickers. Migrants do not or cannot leave, as they have to pay off the debt they took to cover for their journey. They also have to hide from the authorities due to their illegal residence status. ${ }^{11}$ At the end of 2019, there are many cases,

Ministry of Labour - Invalids and Social Affairs, Vietnam's Labour Market Update Newsletter, 22 Quarterly Labour Market Update Newsletter 6, http://www .molisa.gov.vn/Upload/ThiTruong/LMU-So24-Q42019-Eng-final.pdf.

8 Consular Dep't, Ministry of Foreign Affairs of Viet Nam, supra note 1, at 10.

$9 \quad$ Id. at 45.

$10 \quad I d$. at 17.

11 Viet Anh, British Expert Outlines Three Reasons Vietnamese Immigrants are Smugglers, VNEXPRESs (Oct. 29, 2019), https://vnexpress.net/chuyen-gia-anh-neu-ba-ly-do-nguoi -viet-nhap-cu-lau-4003610.html. 
such as the case of 39 Vietnamese workers found dead in a frozen container when attempting to enter the United Kingdoms illegally, or the Austrian police discovered bodies of 71 migrants in a cold container of an abandoned lorry on a highway near the Hungarian border in 2015 etc. that have rung an alarm for both the origin and destination countries on the cruelty of illegal immigration waves existing in our lives. With the dream of changing their lives quickly, these migrants had chosen for themselves a dangerous journey, even risking their lives, to reach the promising lands.

This issue has placed countries in a complex situation about how to protect the fundamental rights of their workers abroad while still upholding the principle of respecting the independence and sovereignty of the host countries? As one of the significant emigrating countries in the world, what challenges does Vietnam currently have to face in ensuring the rights of Vietnamese workers abroad? From this perspective, this study will focus on analyzing: (i) the international and Vietnamese legal framework on the rights of migrant workers, (ii) difficulties and challenges in ensuring the rights of Vietnamese workers who are currently working abroad, (iii) thence, providing specific solutions to better ensure the rights of Vietnamese workers abroad in the future.

International Legal Framework on the Rights of Migrant Workers

Migrant workers are one of the vulnerable groups based on psychological and physiological factors and on working and living environments. Although many international documents have been issued which mentioned both, directly and indirectly, the rights of migrant workers in the world. Furthermore, the protection and promotion of their rights remain a challenge for the international community in general and states' governments in particular. The United Nations (UN) and its specialized agencies, especially the International Labor Organization (ILO), have developed a fairly comprehensive system of international legal instruments and specific treaties on international migration. These organizations have also established implementation monitoring mechanisms on a global scale, which focus on the reporting duty of the State parties on the implementation of relevant international treaties.

\subsection{Core Human Rights Instruments of the United Nations}

In 1948, United Nations adopted the Universal Declaration of Human Rights (UDHR), which became a universal international document stating the basic standards for fundamental human rights. Although it is not a legally binding document, however, UDHR had been widely recognized and became the normative framework for the formation of later important documents on human 
rights, especially the International Covenant on Civil and Political Rights (ICCPR) and the International Covenant on Economic, Social and Cultural Rights (ICESCR) - two of the fundamental international legal instruments on human rights in the world.

These documents recognize equality and non-discrimination as the most important principles in ensuring fundamental human rights while affirming all rights and freedom within these Covenants "without distinction of any kind, such as race, color, sex, language, religion, political or other opinions, national or social origin, property, birth or another status".12 Therefore, state parties are obliged to ensure the enjoyment of human rights and fundamental rights for all, including foreigners and migrants. ${ }^{13}$

The right to migrate is an important right recognized as "a human right and an indispensable condition for the survival and development of individuals." ${ }^{14}$ Under UN's core human rights conventions, freedom of migration is understood as a combination of freedom of movement and residence and the right to leave any country, including their own country, and return to their country. It has been clearly stated in Article 13 of UDHR: "Everyone has the right to freedom of movement and residence within the borders of each state. Everyone has the right to leave any country, including his own, and to return to his country."15

Article 12 of ICCPR also states that all individuals have the right to liberty of movement and freedom to choose their residence in the territory of a country, except for restrictions such as to protect national security or public order. ${ }^{16}$ Furthermore, ICCPR also affirms that aliens residing in the territory of another country could only be expelled from that country pursuant to the law and for compelling reasons such as national security. ${ }^{17}$ However, the right to freedom

12 G.A. Res. 217 (III) A, Universal Declaration of Human Rights, art. 2 (Dec. 10, 1948) [hereinafter UDHR]; G.A. Res. 2200 (XXI) A, International Covenant on Civil and Political Rights, art. 2 (Dec. 16, 1966) [hereinafter ICCPR]; G.A. Res. 2200 (XXI) A, International Covenant on Economic, Social and Cultural Rights, art. 2 (Dec. 16, 1966) [hereinafter ICESCR].

13 UN Human Rights Committee, Letter dated May 26, 2004 from the UN Human Rights Committee, U.N. Doc. C/21/Rev.1/Add.13 (May 26, 2004) Iा 3-10 (stating that “... the enjoyment of Covenant rights is not limited to citizens of States Parties but must also be available to all individuals, regardless of nationality or statelessness, such as asylum seekers, refugees, migrant workers and other persons, who may find themselves in the territory or subject to the jurisdiction of the State Party.").

14 Aining Zhang, Predicaments and Countermeasures of the Protection of Migrant Workers' Human Rights, 17 Journal of Human Rights 223, 226 (2018).

15 UDHR, supra note 12, art. 13.

16 ICCPR, supra note 12, art. 12.

17 Id. art. 13. 
of movement and residence is not absolute. In this regard, the UN Human Rights Committee explained that: "The Covenant does not recognize the right of aliens to enter or reside in the territory of a State party. It is in principle a matter for the State to decide who it will admit to its territory". ${ }^{18}$ Furthermore, ICCPR also comprehensively outlined a set of common rights for everybody to enjoy, including people not citizens of a State.

Similarly, ICESCR also ensures all migrant workers, regardless of their gender and social status, enjoy economic, social, and cultural rights. ${ }^{19}$ Countries are obliged to remove obstacles to the "enjoyment of economic, social and cultural rights by non-citizens, notably in the areas of education, housing, employment, and health". ${ }^{20}$ Besides, ICESCR also provides minimum legal protection to migrant workers by recognizing some fundamental rights such as the right to healthcare, ${ }^{21}$ right to education, ${ }^{22}$ right to housing, ${ }^{23}$ right to work and right at the workplace, ${ }^{24}$ etc., of which the right to work is an important economic right for migrant workers. ICESCR emphasizes that all individuals have the right to equal and favorable conditions of work and that State parties must ensure the right to work for everyone, including immigrants. ${ }^{25}$

Together with the UDHR, ICCPR and ICESCR form the international human rights laws and become the optimal legal shield for ensuring and promoting human rights in all countries, especially for countries that have not ratified specialized international conventions such as the International Convention on the Protection of the Rights of All Migrant Workers and Members of their Families, CEDAw Convention, Convention on the Rights of Persons with Disabilities, etc.

18 Office of the High Comm'r for Human Rights, U.N. Human Rights Comm., CCPR General Comment No. 15: The Position of Aliens Under the CovENANT I 5 (1986), https://www.refworld.org/docid/45139acfc.html.

19 Amnesty Int'l, Living in the Shadows: A Primer on the Human Rights of Migrants 21 (2006), https://www.amnesty.org/download/Documents/80ooo/ pol330o620o6en.pdf.

Office of the High Comm'r for Human Rights, U.N. Comm. on the Elimination of Racial Discrimination, CERD General Recommendation XXX on Discrimination Against Non Citizens |29 (2002) [Hereinafter Cerd]. ICESCR, supra note 12, art. 12. Id. arts. 13,14 . Id. art. 11 .

Id. art. 6(1); AMNESTY INT'L, supra note 19, at 21-22. ICESCR, supra note 11, art. 6(1). 
Following ICCPR and ICESCR, the International Convention on the Protection of the Rights of All Migrant Workers and Members of their Families 1990 (ICMW) was identified as a specialized legal instrument designed to provide specific legal protection for migrant workers group. The adoption of ICMW marks an essential step in the development of international human rights law as well as the awareness of the international community on the importance of migrant workers to politics, economy, and society, at the same time identifies migrant workers and their families as an essential part of society.

In practice, migrant workers are generally unlikely to be welcomed and are not adequately protected in host countries. Therefore, ICMW aims to fill the legal gaps and is expected to become a truly effective legal instrument to "provide minimum universal standards to protect migrant workers and members of their families". ${ }^{26}$ With these considerations, ICMW strives to expand its scope and subject of provisions to cover all migrant workers and their families, regardless of their statuses as documented or undocumented workers according to the standards stipulated in major human rights instruments. ${ }^{27}$ However, due to certain limitations of undocumented migrant workers, the Convention only provides them with minimal legal protection to encourage all migrants and employers to respect and comply with the laws and procedures established by the countries. ${ }^{28}$

On the first important point of this Convention, it further identifies the definition of a migrant worker as mentioned in the ILO Convention No 97, 1949, and added the definition of members of the family. In addition, the Convention provides for a system of human rights of migrant workers that is quite comprehensive and specific. It is a very important basis for protecting the rights and interests of migrant workers in practice. It is arguably the Convention's most outstanding contribution to the protection of this group. Under the ICMW, migrant workers are understood as people who will, are, and have participated in an income-generating activity in a country where they are not citizens. In addition, the Convention also introduced the concept of "their family" as only

26 Shirley Hune \& Jan Niessen, The First UN Convention on Migrant Workers, 9 NETHE RLANDS QUARTERLY OF HuMAN Rights 130, 131-32 (1991).

27 Id. at $130,135$.

28 G.A. Res. 45/158, pmbl. (Dec. 18, 1990); James A.R. Nafziger \& Barry C. Bartel, The Migrant Workers Convention: Its Place in Human Rights Law, 25 International Migration REVIEW 771, 777 (1991). 
those who are married to the migrant workers or have a similar relationship to marriage, as well as children and other dependents who are recognized as family members under applicable law and the signed agreements between the countries concerned. It means that they are only considered a member of migrant workers' families and protected the fundamental rights when they genuinely have a marriage relationship with a migrant worker.

Like other vulnerable groups such as women, children, ethnic minorities etc., rights specified in the ICMW take into account the circumstances and specific needs of this particular group. These particular rights are only applicable to migrant workers and not to any other social group. ${ }^{29}$ The content of ICMW focuses on the rights of migrant workers in two main groups, namely: (i) the fundamental human rights of all migrants, whether documented or undocumented, and their family members must be guaranteed including rights in criminal proceedings, right to privacy, right to be treated equally as citizens of the host countries regarding working conditions, social security, right to transfer income and right to be informed, etc., and (ii) additional rights applicable to legal migrant workers and members of their families such as: right to temporary absence, right to freedom of movement, right to be treated equally as the citizens of the receiving country, other rights if the employer violates their contracts. In ICMW, non-discrimination is also referred to as the fundamental principle to avoid creating discrimination between migrant workers and citizens of the host country. However, like other international documents, ICMW has not yet explained specifically the content of this principle.

It should be noted that, according to the general principles of international human rights law, some of the above rights, including freedom of movement, freedom to reside within the territory of the country where there are employed, freedom of association, and unions, may be subject to statutory restrictions which are necessary to protect national security, public order, public health or morals or individual's rights, and freedom..$^{30}$ In addition, similar to other international human rights treaties, ICMW also regulates states' reporting and monitoring regime. Accordingly, member states will be required to submit national reports on the convention's implementation every five years and may also be required to submit Adhoc reports as required by the overseeing committee of the convention in case any serious problem arises. Besides, the convention provides the mechanism that allows a Member State to complain

\footnotetext{
29 The Vietnamese Lawyers Association, The Protection of the Rights of Immigrant Workers, INT'L, REgionAL \& NAT'L L. \& PRAC., 2008, at 4O-41, https://asean.org/storage/2016/o8/ V4_MWs-Rights-in-International-20o8.pdf. Id. at 51 .
} 
to the Convention Oversight Committee against the failure of another Member State to fulfil its obligations under the Convention (Article 76); and the mechanism that allows individuals to complain to the Supervisory Commission about the Government's failure to fulfil its obligations under the Convention (Article 77). However, up to now, all member states of the convention have reserved these two mechanisms above. It seems like the general situation of other international human rights conventions that a few member states accept the authority of the Convention Oversight Committee in receiving and resolving complaints from states and individuals. ${ }^{31}$

In fact, labor migration is becoming an increasingly complicated problem at the global level, however, according to several researchers, it seems that international conventions in this area have not indeed received attention from countries around the world. As of 19 January 2020, ICMW has 55 state parties, a relatively modest number compared to other international human rights treaties of the UN. The convention has placed too many responsibilities on the host countries while "ignoring" the origin states. ${ }^{32}$ It makes the convention less "attractive" to countries. The harmony and balance of obligations and responsibilities between the receiving country and the country of origin must be considered and divided appropriately to avoid creating "distinct" obligations and considered a "burden" to receiving countries. However, it is undeniable that this convention has contributed to the completion of the legal framework for the protection of rights of migrant workers in the world, and it is still seen as one of the cores and specialized human rights instruments exclusively for migrant workers and members of their families. Shortly, people can expect those nations will properly appreciate the good values constructed by the Convention to accept the obligations more easily.

\subsection{ILO's Conventions on the Rights of Migrant Workers}

Being developed on the foundations of universal documents on human rights of the UN, Convention No. 97 concerning Migration for Employment (Revised 1949) and Convention No. 143 concerning migrations in abusive conditions and the promotion of equality of opportunity and treatment of migrant workers (Supplementary Provisions) are core conventions of the ILO on the issues of migrant workers as they refer to problems that arise throughout the entire

$31 \quad I d$.

32 International Convention on the Protection of the Rights of All Migrant Workers and Members of their Families, U.N. Hum. RTs., Off. High Commissioner, https://indi cators.ohchr.org (last visited Apr. 24, 2021). 
labor migration process, from the time the workers are in their countries of origin, during the employment in the host countries until their return. ${ }^{33}$

According to Convention No. 97 of ILO, a migrant worker is a person who migrates from one country to another to find employment, includes any person regularly admitted as a migrant for work. This definition does not include frontier workers, short-term entry of liberal professions and artists, and seamen (Article 11). This understanding is repeated in Convention No. 143. Still, the Convention adds two more groups which are (i) seamen, persons coming specifically for purposes of training and education, and (ii) employees of organizations or undertakings operating within the territory of a country who have been admitted temporarily to that country at the request of their employer to undertake specific duties or assignments, for a limited and defined period, and who are required to leave that country on the completion of their duties or assignments (Article 11).

The ILO's Conventions noted: "all migrant workers are protected by these Conventions without distinction of the types of migrant workers as well as not based on the principle of reciprocity between countries". To implement this provision, Convention No. 97 imposes an obligation on state parties to undertake the activities to (i) support and protect migrant workers such as: facilitating journey and reception of migrants for employment, ${ }^{34}$ maintaining and providing adequate and free service to assist migrants for employment (Article 2), medical services and living conditions for migrants for employment and members of their families (Article 5), etc. (ii) equal treatment for migrant workers such as: apply national treatments with migrants for employment (Article 6), allow migrants for employment to transfer earnings and savings abroad (Article 9), etc.

To supplement for Convention No. 97, Convention No. 143 mentions aspects that Convention No. 97 had not mentioned, such as (i) requiring state members to determine whether there are illegally employed migrant workers on their territory and passing through their territory and whether migrant workers are employed illegally (Article 2); (ii) adopting necessary and appropriate measures to suppress clandestine movements of migrants for employment and illegal employment of migrants (Article 3); (iii) prosecuting authors of manpower trafficking (Article 5); (iv) taking necessary measures to facilitate

33 Labor and Soc. Publ'g House, International Law on the Rights of Vulnerable Groups 135 (2011).

34 International Labour Organization [ILO], Migration for Employment Convention (Revised), art. 4, ILO Doc. C97 (July 1, 1949), https://www.refworld.org/docid/3ddb64057. html. 
the reunification of the families of all migrant workers legally residing in its territory, etc.

In general, both of these Conventions affirm that migrant workers will enjoy the same fundamental human rights as native workers. The most significant limitation of these two Conventions is that they only mentioned the groups, which are legal migrant workers themselves but have yet to consider the right of illegal migrant workers and members of their families. Maybe, that is the reason why they also have a limited number of members. By 8 March 2021, Convention No. 143 (effective from og December 1978) only has 26 state parties $^{35}$ while Convention No. 97 (effective from 22 January 1952) has $5^{1}$ state parties. ${ }^{36}$

Besides, at the regional level, Vietnam and ASEAN countries also strived to develop standard documents to address legal issues regarding migrant workers in the region, such as the ASEAN Declaration on the Protection and Promotion of the Rights of Migrant Workers adopted in Cebu in 2007 (Cebu Declaration in short), ASEAN Consensus on the Protection and Promotion of the Rights of Migrant Workers 2017, etc. In general, these documents called on ASEAN countries to ensure the rights of migrant workers by implementing specific obligations such as protection of workers from abuse, discrimination, or violence; providing essential services for migrants such as necessary information about the receiving country, legal consulting services to resolve disputes or complaints etc. ${ }^{37}$ In addition, ASEAN documents also call on countries to increase cooperation to solving issues related to migrant workers and members of their families, at the same time, to harmonize national law with ILO's basic laboring standards. Although there have been many efforts to legalize regulations on the rights of migrant workers, in practice, ASEAN has yet established binding rules and clear mechanisms to promote decent working conditions and basic laboring standards at the regional level. The Cebu Declaration is not a legally binding document, therefore, its effects on member states are still very limited.

35 Ratifications of $C_{143}$ - Migrant Workers (Supplementary Provisions) Convention, 1975 (No. 143), INT'L LAB. ORG., https://www.ilo.org/dyn/normlex/en/f?p=100o:1130o:o::NO:11 300:P1130o_INSTRUMENT_ID:312288 (last visited May 21, 2021).

$36 \quad$ Ratifications of Cog7 - Migration for Employment Convention (Revised), 1949 (No. 97), INT'L LAB. ORG., https://www.ilo.org/dyn/normlex/en/f?p=NORMLEXPUB:1130o:o::NO:1130o :P1130O_INSTRUMENT_ID:312242:NO (last visited May 21, 2021).

The asean Secretariat, ASEAN Consensus on the Protection and Promotion of the Rights of Migrant Workers 18, 23 (2019), https://asean.org/ storage/2019/o1/3-March-2018-ASEAN-Consensus-on-the-Protection-and-Promotion-of -the-Rights-of-Migrant-Workers.pdf. 


\section{The Rights of Migrant Workers in the Vietnamese Legal System -} Current Situation and Challenges

\subsection{Vietnamese Legal Framework on the Rights of Migrant Workers}

Labor migration through labor export has made an outstanding contribution to Vietnam's economic development by "boosting the economy through remittances and improving Vietnam's skill base". 38 The Vietnamese Government also believes that overseas labor migration will create "better income and employment opportunities for Vietnamese workers, improving the livelihoods of the population, reducing poverty, stabilizing society and building a highly skilled and professional workforce". 39

As mentioned above, Vietnam is now one of the significant emigrating countries in the world. Therefore, it is essential to recognize and secure the rights of Vietnamese migrant workers to ensure their legitimate rights and interests. At the same time, limit infringement of rights and risks that could make them victims of overseas trafficking crimes.

\subsubsection{Rights of Vietnamese Migrant Workers under Contract}

In Vietnamese law, the concept of 'workers working abroad' refers to those who go abroad to work under a contract. In comparison with the United Nations Convention on the rights of migrant workers and their family members, this category of objects falls under the category of 'documented migrant workers'. Thus, in terms of the connotation, the concept of 'workers working abroad' is narrower than the concept of migrant workers. ${ }^{40}$

Vietnam began sending unskilled workers abroad through licensed agencies from November 1991 based on Decree No. 370/HĐвт of the Council of Ministers dated November 9, 1991, on the promulgation of regulations on sending Vietnamese workers abroad to work for a definite time. The 7th National Party Congress in 1991 proposed the "Strategy for stability and socio-economic development up to 2000", in which the direction to solve the problem of employment is identified as: "... creating jobs ...., building infrastructure, expanding the service sector, labor export”. This highest policy orientation

38 Ruth Bowen \& Do Van Huong, Women in International labour Migration from Vietnam: A Situation Analysis 23 (2012), https://asiapacific.unwomen .org/-/media/field\%2ooffice\%2oeseasia/docs/publications/2013/women\%2oin\%20 international\%2olabour\%2omigration\%2ofrom $\% 2$ oviet\%2onam\%2oa\%2ositua tion\%2oanalysis.pdf?la=en.

39 Consular Dep't, Ministry of Foreign Affairs of Viet Nam, supra note 1 at 15.

40 Labor and Social Publ'g House, supra note 33, at 120. 
allows the expansion of labor export activities in Vietnam in the new period. ${ }^{41}$ Following that, Directive No. 41/Ст-TW of the Politburo continues to affirm: "exporting labor and experts is a socio-economic activity contributing to the development of human resources, creating jobs, income and improving skills for workers, as well as increasing foreign currency revenues for the country. Furthermore, labor and expert export was an important and long-term strategy contributing to building a workforce for the Government to speed up industrialization and modernization. ${ }^{42}$ From these policies, labor export activities were initially legalized in the Labor Code passed by the National Assembly on June 23, 1994, and its implementing documents. Since then, the law on migrant workers in Vietnam has continued to be strengthened and developed with a series of important documents built into the national legal system.

The 2013 Constitution clearly states that "Citizens have the right to free movement and residence within the country, and the right to leave the country and to return home from abroad".43 Overseas Vietnamese are an inseparable part and a resource of the community of Vietnamese nationalities. The protection of the legitimate rights and interests of Vietnamese citizens and legal entities in foreign countries is extremely necessary, demonstrating the State's responsibility towards citizens ... ${ }^{44}$ Under the 2013 Constitution, Vietnam has concretized the rights of Vietnamese workers abroad in some legal documents such as Law on Vietnamese Nationality 2008 (amended and supplemented in 2014); Law on Overseas Representative Offices of the Socialist Republic of Vietnam 20o9; Law on Vietnamese workers working abroad under contracts 2006, Law on Human Trafficking Prevention and Control 2011, Penal Code 2015 (revised in 2017 ); etc. There are also agreements on regulations on land border management between Vietnam and bordering countries.

The primary legislative documents that govern migrant workers in Vietnam are the 2012 Labor Code and the 2006 Law on Vietnamese Guest Workers under Contract. The Labor Code 2012 stipulates the rights and obligations of

41 Đại hội đại biểu toàn quốc lần thứ XIII của Đảng [XIII Nat'l Cong. of the Party], Chiến lược ổn định và phát triển kinh tế - xã hội đến năm 2000 [Strategy for Socio-Economic Stability and Development to 2000], ĐẠI HộI ĐẠI BIỂU TOÀN QUỐC LẦN THỨ XIII CỦA ĐẢNG [DHD] (Aug. 17, 2020, 3:55 PM), https://daihoidang.vn/chien-luoc-on-dinh-va-phat-trien -kinh-te-xa-hoi-den-nam-20oo/48o.vnp.

42 Chỉ thị 41/CT-TW Về Xuất Khẩu Lao động Và Chuyên Gia [Directive No. 41 CT/TW on Labor Export and Experts], Ministry of Politics (Sept. 22, 1998).

43 HiẾn Pháp [Constitution] art. 23 (2013).

44 Nghị quyết số $36-N Q / T W$ về công tác đối với người Việt Nam ở nước ngoài [Resolution No. 36-NQ/TW on overseas Vietnamese], Ministry of Politics (Mar. 26, 2004). 
employees in labor relations. The State recognizes the importance of gender equality and the need to develop and implement equal policies on employment, insurance, and society to protect female workers, especially in recruitment and employment while pregnant or on maternity leave. ${ }^{45}$ The State encourages enterprises, agencies, organizations, and individuals to seek and expand the labor market to create more jobs for Vietnamese workers abroad. At the same time, Vietnam affirms the importance of labor migration abroad under contract complying with the Vietnamese laws, the laws of the receiving countries, and international treaties (if any) between Vietnam and contracting states. ${ }^{46}$

The 2006 Law on Vietnamese Guest Workers under Contract also stipulates the rights and obligations of enterprises, non-business organizations sending Vietnamese workers to work abroad under contracts, and other relevant organizations and individuals. The scope of this Law is quite wide when trying to cover all subjects involved in international labor migration. ${ }^{47}$ In addition, this Law also sets out requirements and conditions for enterprises to grant licenses for sending Vietnamese workers abroad; responsibility for employees in case employees die, suffer from occupational accidents, abuse, exploitation of their health, honor or dignity, infringed or harmed. In addition, the Government of Vietnam also requires Vietnamese employees to comply with the signed contractual agreements, the employer's labor regulations, the laws and regulations of Vietnam and the receiving countries, to actively participate in training courses, social insurance and maintain the values, good customs of Vietnam, and other responsibilities. ${ }^{48}$

In general, similar to the provisions of international laws, Vietnamese workers, when working abroad, firstly enjoy fundamental human rights such as the right to life, the right to health care, and the right to access information, etc. The organizations and individuals licensed to send workers abroad to work are obliged and responsible to strictly comply with the contents of the contracts with the employees, ensuring the correct procedures according to the provisions of the law and not allowed to take advantage of labor contracts to perform acts such as abusing activities of sending workers abroad to organize the sending of Vietnamese citizens abroad; sending workers abroad without registering contracts with competent state agencies under the 2006 Law on

\footnotetext{
45 Bộ luât Lao Động [Labor Code], No. 10/2012/QH13 art. 4(7) (June 18, 2012).

$46 \quad$ Id. art. 168.

47 Luật Người Lao động đi Làm Việc ở Nước Ngoài Theo Hợp đồng [Law on Vietnamese Guest Workers], No. 72/2006/QHi1 art. 6 (Nov. 29, 2006).

48

Id. art. 45 .
} 
Vietnamese Guest Workers under Contract etc. In addition, as migrant workers, Vietnamese workers abroad also have some typical rights such as:

- The right to be informed about the policies and laws of Vietnam on the migrant workers; laws, customs, and practices of the host country; rights and obligations of the parties when going to work abroad. This right is especially important for workers preparing to work overseas to equip them with the knowledge to protect their interests, to avoid deception cases when committing to the rights and obligations in the contract. In addition, understanding the customs and practices of the host country will help workers integrate soon into life abroad. ${ }^{49}$

- The right to enjoy salaries, remunerations and other incomes, medical examination and treatment, social insurance and other benefits provided for in contracts, international treaties, and international agreements to which Vietnam is a party.

- The right to have his/her lawful rights and interests protected while working abroad by the enterprise, non-business organization, offshore-investing organization or individual and by the foreign-based Vietnamese diplomatic mission or consulate following the Vietnamese law, the law of the host country as well as the international law and practice; to be advised on and supported in the exercise of their rights and enjoyment of benefits stated in the labor contract or internship contract (Article 44 (3)).

- The right to transfer home his/her salary, remunerations, incomes, and other personal properties following the laws of Vietnam and the host country (Article 44(4)).

- The right to enjoy the benefits from the overseas employment support fund under the provisions of law (Article 44(5)). On August 31, 2007, the Prime Minister issued Decision No. 144/2007/ QĐ-TTg on the establishment, management, and use of the Overseas Employment Support Fund. Accordingly, the Overseas Employment Support Fund employees will support the employees working abroad to foster their skills, foreign languages, and knowledge; assist in solving risks.

- The right to lodge complaints or denunciations or initiate lawsuits against illegal acts in sending workers abroad (Article $44(6)$ ).

Concerning regulations exclusively for female migrant workers abroad, to ensure equal rights for them to work and access necessary legal services, the Government of Vietnam has also paid attention to develop their own rules.

49 Min Chen, The Impact of Expatriates' Cross-Cultural Adjustment on Work Stress and Job Involvement in the High-Tech Industry, Frontie rs Psychol. (Oct. 9, 2019), https://www. frontiersin.org/articles/10.3389/fpsyg.2019.02228/full. 
The Government issued and implemented the Law on Gender Equality in 2006, including equality in recruitment, working conditions, wages, social insurance, and other work-related conditions. On the other hand, the Government has identified a list of jobs where Vietnamese workers, especially female workers, are at high risk of labor exploitation and abuse, such as dancers, singers, and massages working at restaurants, hotels, or entertainment centers; jobs that must be in constant contact with explosives, noxious substances, frequent work in a place where there is a lack of air, high pressure (underground, ocean), et cetera. ${ }^{50}$ By warning these jobs, the Government of Vietnam strives to extend protections for Vietnamese female workers while working abroad.

In addition to the above rights, Vietnamese workers working abroad under the contract are also entitled to the rights corresponding to the form of contract that sends them to work overseas. At the same time, their legitimate rights and interests are protected by the State of Vietnam. In addition, Vietnam has also developed a Code of Conduct to ensure a responsible and ethical recruitment process developed by the Vietnam Association of Manpower and Supply in 2010 (updated in 2018); and, the establishment of Vietnamese Labor Advisory Centers to work abroad has helped increase workers' access to information and justice. The role of trade unions in monitoring law implementation and protecting workers' rights is also promoted through cooperation with trade unions in the host countries.

Organizations and individuals that commit criminal violations in this field will be sanctioned under the 2015 Penal Code (amended in 2017) for crimes such as Human trafficking (Article 150), Trafficking of a person under 16 (Article 151). Administrative sanctions are also stipulated in the Law on Vietnamese Worker working abroad under contracts 2006 and Decree No. 28/2020/NĐ-CP dated $\mathrm{O} 1 / 3 / 202 \mathrm{O}$ of the Government regulating the sanctioning of administrative violations in labor, social insurance, sending Vietnamese workers to work abroad under the contract. Accordingly, depending on the behavior and the seriousness of the violation, the offender can be subject to a warning or a fine. In addition, it may be accompanied by one or several additional penalties. ${ }^{51}$

On November 13, 2020, the National Assembly of Vietnam passed the amended Law on Vietnamese workers working abroad under contracts, which

50 QuyĐịnh Chi Tiết VÀ Hướng Dẫn Luật Người Lao Động Việt Nam Đi Làm Việc Ở Nước Ngoài Theo Hợp Đồng [Detailing and Guiding the Implementation of a Number of Articles of the Law on Vietnamese Laborers to Work Abroad Under the Contracts], 126/2007/ND-CP If 2 (Aug. 1, 2007).

Bộ Luật Hình Sự [Criminal Code], No. 100/2015/QH13 art. 9 (Nov. 27, 2015). 
will enter into force from January 1, 2022. Compared with the current law, the amended law has 31 new points belonging to 8 major content groups. It continues to regulate state policies on Vietnamese workers working abroad under contracts, as well as rights, obligations, and responsibilities of overseas workers, enterprises, public service providers, and related agencies, organizations. The law also promogulated the protection of the legitimate rights and interests of those workers. In particular, Article 7 of the new law explicitly states 17 prohibited acts, such as: enticing, seducing, promising, mistakenly advertising, providing false information or other tricks to deceive the employee; taking advantage of activities of sending workers abroad to organize illegal exit, trafficking, exploitation, forced labor or other illegal acts.

\subsubsection{Rights of Undocumented Vietnamese Workers Abroad}

Besides legal workers, the number of Vietnamese workers migrating abroad by informal channels is quite large, and there aren't complete statistics on this number. Illegal migrant workers have to live on the margins of society, so they are both vulnerable to exploitation and ideal for criminal gangs to take advantage of and manipulate. ${ }^{52}$

The law and guidance documents only regulate the employment relationship between workers working abroad through official channels. In contrast, although without officially available data, Vietnamese laborers working through informal ways is quite high. They may be migrants looking for work through informal routes or go by the official routes and then run away and do informal work, or those who do not return home when their contract is expired. In fact, undocumented workers face many risks when working "underground" in foreign countries. They are often mistreated, abused, or easily victimized by various crimes, including human trafficking.

In Vietnam, regulations related to ensuring the rights of undocumented migrant workers are still quite poor and are still being proposed for improvement. There are only a few relevant documents such as the 2011 Law on Human Trafficking Prevention and Control, and the 2015 Penal Code (amended in 2017) that recognizes crimes such as organizing, brokering the illegal entry, exit, or stay in Vietnam of another person (Article 348), organizing, brokering illegal emigration of another person (Article 349) ..., Decision No. 17/2007/QĐ-TTg of the Prime Minister that promulgates a regulation on accepting and supporting community reintegration for women and children returned from overseas trafficking, etc. 
From an international perspective, Vietnam has also signed some Agreements on the return of Vietnamese citizens who are not allowed to reside abroad with several countries such as Germany, Poland, Canada, the UK, Switzerland, Norway, Czech, United States, Sweden, Belgium, France, etc..$^{53}$ All these agreements are identified based on the principle of reciprocity to cooperate in solving problems related to receiving citizens illegally residing in one of the State parties' territory to prevent the increase in illegal migration. Also, according to the provisions of these agreements, to be accepted to return, the returnee must prove their nationality through one of the documents such as passport, identity card, nationality certificate, etc. In general, the provisions of these documents are deemed to be limited to the general provisions on illegal immigration and the responsibilities of individuals and organizations sending workers abroad. Still, there are no regulations to protect the rights of illegal Vietnamese workers working abroad. It is a huge gap for all types of trafficking crimes.

In summary, Vietnam's legal system and policies on migration are still quite limited and are still being improved. Migrant workers, whether legal and documented or work illegally and undocumented, are still Vietnamese citizens, so they still need the State to ensure their fundamental rights in the Constitution. Therefore, there are some shortcomings such as the lack of regulations to ensure the legitimate rights and interests of Vietnamese citizens during the migration process (before leaving the country - while abroad - when repatriation and reintegration), or the incomplete legalization of regulations related to different types of Vietnamese citizens' migration abroad. This practice leads to poor enforcement and needs to be considered in time to ensure the full enjoyment of the rights of Vietnamese workers abroad.

\subsection{Specific Policies of the Vietnamese Government for Overseas Workers Returning Home Due to the CoviD-19 Pandemic}

Since the beginning of 2020, the world economy has been on the brink of a recession in the aftermath of the CoviD-19 pandemic. International organizations and financial institutions estimated that the global economy would witness the most severe economic depression in decades. The International Monetary Fund has accordingly lowered the global economic growth forecast

53 Consular Dep't, Ministry of Foreign Affairs of Viet Nam, List of Treaties, Bilateral Agreements on Getting Back Citizenship 4 (2020), https://lanhsu vietnam.gov.vn/Lists/BaiViet/Bài\%2oviết/DispForm.aspx?List=dc7c7d $75 \% 2 \mathrm{D} 6 \mathrm{a} 2 \% 2{ }_{2} \mathrm{D} 4$ 215\%2Dafeb\%2D47d4bee7oeee\&ID=138 (last visited Dec. 9, 2020). 
by 1.9 percentage points compared to its former forecast in April 2020, to negative $4.9 \%$. Similarly, according to the World Bank, the global economic growth projection is negative $5.2 \%$, which is the steepest decline since the Great Depression in the 1930s. According to the evaluation of the International Labor Organization, the economic and labor crisis which covid-19 causes could add up to 25 million unemployed people globally. ${ }^{54}$ After social distancing and lockdown orders from governments, many workers lost their jobs, which had a serious impact on their income. The countries need to have consistent and rapid coordination policies at both national and global levels on demonstrating multilateral cooperation to limit health crises for workers and their families as well as economic impacts from the CoviD-19 pandemic.

Although there are specific achievements in the early stage of fighting the COVID-19, Vietnam's economy has been suffering considerable repercussions due to the pandemic. According to the preliminary statistics, to date, more than 5,00o Vietnamese workers working overseas have returned to Vietnam as a consequence of the CoviD-19 pandemic. Almost all industries have been considerably impacted by the pandemic leading to a significant reduction in the labor force and a high unemployment rate. The country's Gross Domestic Product (GDP) recorded in the second quarter of 2020 showed a minimal increase of $0.36 \%$ compared to the previous year, which was the lowest increase within the 2011-2020 period. The labor force has decreased by more than 2 million people compared to the previous quarter in the same period of the former year. The unemployment rate of people at labor age in urban areas has been recorded as $4.46 \%$, which is the highest in 10 years.

To support overseas Vietnamese workers returning home to overcome this crisis, the Government of Vietnam has introduced fast and practical response programs to best guarantee the rights of Vietnamese workers. According to the Joint Circular No. 16/2007/TTLт-вцDтвхн-втP dated 4 September 2007, the employee is reimbursed the brokerage fee in case of force majeure (natural disaster, war, bankruptcy, etc.). If it is not the fault of the employee, the enterprise shall request the broker to refund employees a part of the brokerage according to the principle that the employee who has worked less than $50 \%$ of the time under the contract will receive $50 \%$ of the paid brokerage. The employee who has worked $50 \%$ of the time under the contract or more is not entitled to receive the brokerage fee. In case the broker cannot be claimed, the enterprise shall reimburse the employee according to the above principle

54 Press Release, Int'l Labor Org., Almost 25 Million Jobs Could Be Lost Worldwide as a Result of COviD-19, Says ILO (Mar. 18, 2020), https://www.ilo.org/global/about-the-ilo/ newsroom/news/WCMS_738742/lang--en/index.htm. 
and be accounted for reasonable expenses when calculating taxable income in accordance with Vietnam's Law on Corporate Income Tax.

In addition, for reimbursement service, according to Clause 3, Section III of the above Joint Circular, in case overseas workers returning home ahead of schedule due to force majeure or not due to the employee's fault, the enterprise is only allowed to collect the service fee according to the actual time (number of months) the employee was working abroad. In some special cases decided by the Minister of Labor, Invalids, and Social Affairs, overseas workers can receive a maximum of 5 million vND per case. Depending on the epidemic situation, the authorities shall support workers and enterprises if needed. ${ }^{55}$

Apart from those supporting measures, from February 2020, Vietnam has reviewed Vietnamese workers working abroad under contracts for infection and suspected CoviD-19 infection. ${ }^{56}$ Vietnamese workers must take the initial measures to prevent the COVID-19, strictly complying with the medical requirements of the Vietnamese authorities and host countries. ${ }^{57}$ In addition, the Government advocates to simplify administrative procedures for businesses, reduce pre-check, increase post-check, strengthen online settlement (online) for contract registration, licenses for businesses, temporarily suspending periodic inspections of enterprises until the end of the second quarter of 2020. The Department of Overseas Labor, the Inspector of the Ministry of Labor, Invalids and Social Affairs, only conducts irregular inspections when having complaints and questions from employees, employees' relatives, and feedback from news agencies and newspapers.

In addition to material support, from February 2020, Vietnam has reviewed Vietnamese workers working abroad under contract who were confirmed or suspected of Covid-19 disease. In particular, the Government noted that, when it is necessary to leave Vietnam, Vietnamese workers must take steps to

55 Tú Giang, Hỗ trợ lao động Việt Nam làm việc ở nước ngoài mất việc vì COVID-ı19 [Support Vietnamese Workers Working Aboard Who Lose Their Jobs Due to the COVID-19], DCVN (Apr. 1, 2020, 10:24 AM), https://dangcongsan.vn/xa-hoi/ho-tro-lao-dong-viet-nam-lam -viec-o-nuoc-ngoai-mat-viec-vi-covid-19-551614.html.

56 Minister of Labor, Công diện số or/CĐ-LĐTBXH Về tăng cường các biện pháp phòng, chống dịch bệnh viêm đường hô hấp cấp do chủng mới của vi rút Corona gây ra [Affairs, Document No. o1/CĐ-LDTBXH on Strengthening Measures to Prevent and Control Acute Respiratory Infections Caused by New Strains of Corona Virus], Cộng HòA XÃ HộI ChỦ NGHĨa Việt Nam (Feb. 2, 2020), http://www.molisa.gov.vn/Pages/tintuc/chitiet .aspx?tintucID=222250.

57 Ngan Anh, Chưa có lao động Việt Nam làm việc ở nước ngoài theo hợp đồng bị nhiễm Covid19 [No Vietnamese Workers Abroad Under a COVID-19 Contract are Infected], NHÂN DÂN (Feb. 13, 2020, 11:17 PM), https://nhandan.com.vn/tin-tuc-xa-hoi/chua-co-lao-dong-vie t-nam-lam-viec-o-nuoc-ngoai-theo-hop-dong-bi-nhiem-covid-19-449451. 
prevent themselves from the CoviD-19, strictly comply with medical requirements of the authorities in receiving countries. On April 3, 2020, the Ministry of Labor, Invalids and Social Affairs issued a telegram on Strengthening the implementation of urgent measures to prevent and control the CoviD-19 epidemic during the peak phase, whereby the Minister directed the Vietnamese labour-management abroad performs activities such as:

- Communicate with overseas workers to comply with the host country's regulations on COVID-19 prevention and control, limit to move to high-risk areas;

- Strengthen the management to protect overseas workers in case of being affected by Covid-19;5

- Setting up phone hotlines, contact points in the Vietnamese community in the host country to promptly grasp the situation of the overseas workers;

- Coordinate with the authorities of the host country to ensure that workers are tested, isolated, and treated in case of suspected or infected by CoviD-19;

- Coordinate with the host country to claim for employees' wages on leave due to COVID-19, deal with foreign enterprises on the extension of stay, extending the contract, or ensure overseas workers return safely and legally in case of an exit. ${ }^{59}$

Thus, in the context of the complicated development process of CoviD-19 in many countries, Vietnam, with very timely policies, has supported Vietnamese labor to work abroad. This is an important basis for Vietnamese authorities to continue implementing activities to protect citizens in foreign countries.

\subsection{Challenges in Ensuring the Rights of Vietnamese Migrant Workers}

3.3.1 Exacerbation of Illegal Labor Migration and Associated Legal Gaps According to the Iом report, the annual number of Vietnamese workers working under contracts abroad is vast, but on the other hand, there are incomplete statistics on the number of Vietnamese workers that was illegally residing in a foreign country. Ha Tinh is one of the provinces with the largest number of workers working abroad in Vietnam, currently estimated to have nearly 68 , ooo people working in more than 6o countries and territories. This number of workers work mainly in Korea, Japan, Taiwan, Thailand, and Europe. If calculating the number of migrant workers who migrate abroad freely and do

$5^{8}$ Về Tăng Cường Thực Hiện Các Biện Pháp Cấp Bách Phòng, Chống Dịch Covid-19 Trong đợt Cao diểm [Promotion of Implementation of Measure for COVID-19 Prevention and Control of COVID-19 in High Peak], No. o2/CĐ-LDTвXн I 3.1 (Apr. 3, 2020).

59 Tiếp Tục Thực Hiện Các Biện Pháp Phòng, Chống Dịch Covid-rg Trong Tình Hình Mới [Continues to Take Measures to Prevent and Control COVID-19 Epidemic in the New Situation], No. 1945/LDTBXH-QLLDNN (June 2, 2020). 
not have a work permit of the host country, Ha Tinh has over 35,0oo people. ${ }^{60}$ In particular, during the Covid-19 epidemic outbreak, thousands of overseas Vietnamese workers returned home, among whom relatively large number of illegal workers showed deficiencies in current overseas workers' management.

There are many reasons for Vietnamese workers to migrate abroad illegally. According to the IOM, most of them accept migration because of economic pressure, forced by their families to migrate, wanting to escape domestic violence, divorce, indebtedness, or other problems. However, some people have become "successful" smuggled immigrants, sending money back to their families makes others want to follow this path, even though they have to take risks. ${ }^{61}$ According to Dang Nguyen Anh, in addition to exporting unlicensed labor, one of the reasons that make workers choose unorthodox routes is the promises and temptations of individuals called brokerage agents in rural areas. ${ }^{62}$ Besides, the procedure is cumbersome. The waiting time is long; document and recruitment costs, indirect costs incurred, and the lack of official information also lead to more workers looking for informal channels.

In addition, as analyzed above, Vietnamese law still has a lot of gaps related to illegal migrant workers. Although the Penal Code deals with crimes related to illegally sending Vietnamese workers abroad, sanctions and enforcement measures to prevent this situation are, in fact, not strong enough to prevent illegal "silent" flows of migrants from going abroad.

There Are Still Difficulties in Controlling the Activities of Labor

Export Enterprises, Especially in Training and Retraining and

Collecting Labor Fees

By the end of 2019, the number of labor export enterprises in Vietnam is about 421 (15 state-owned enterprises). According to the 2006 Law on Vietnamese Guest Workers under Contract and guidance documents, sending Vietnamese workers abroad is in a conditional business field. Only Vietnamese enterprises that meet conditions on capital, financial capacity, organizational

6o Phạm Trường, Hơn 35.00o Người Hà Tĩnh Cư Trú Bất Hợp Pháp ở Nước Ngoài [More Than 35,00o Ha Tinh People Illegally Reside Overseas], Zing News (Dec. 15, 2019), https:// zingnews.vn/hon-35ooo-nguoi-ha-tinh-cu-tru-bat-hop-phap-o-nuoc-ngoai-post1o25568 .html.

61 Viet Anh, Chuyên Gia Anh Nêu Ba Lý Do Người Việt Nhập Cu' Lậu [British Expert Mentioned Three Reasons Why Vietnamese People Illegally Immigrate], VNExpress (Oct. 29, 2019), https://vnexpress.net/chuyen-gia-anh-neu-ba-ly-do-nguoi-viet-nhap-cu-lau-4003610 .html.

62 Nguyen Anh Dang, Labour Migration From Vietnam: Issues of Policy and Practice 12 (Int'l Labor Org., Working Paper No. 4, 2008). 
apparatus, and facilities for this activity by current law may be considered for a license to send Vietnamese workers to work abroad under the contract. However, in reality, some enterprises do not meet the conditions prescribed by law but still recruit labor export, leading to a situation in which enterprises are not able to send workers abroad safely according to the Agreement. Then, enterprises that provide labor export services often do not concentrate or cannot control the workers' activities in the receiving country. Many enterprises open services without registration, do not directly recruit workers or do not seriously comply with training requirements and foster knowledge for employees. Some labor recruitment agencies pay little attention to equipping employees with sufficient awareness and understanding of their rights and obligations under labor contracts. The training courses are poorly planned and inadequate with the needs of workers with specific notices to migrant female workers, etc.

In addition, according to the provisions of this Law and Circular 21/2007/ TT-BLDTBXH dated October 8, 2007, the recruitment of workers to work abroad must be done publicly, directly, and is not allowed to collect recruitment fees from employees. ${ }^{63}$ However, the recruitment process for international migrant workers is often multifaceted, requiring the participation of many organizations and individuals. ${ }^{64}$ To send labor to work abroad, the employees had to pay a huge amount of money to the labor export agents and brokers. Most of them have to rely on family members, banks, and labor suppliers to cover the cost of working abroad. Thus, in most cases, before going abroad to work, workers were heavily indebted to loans ${ }^{65}$ despite the State's efforts in providing financial support channels for them through funds and state banks from which workers can borrow money at low-interest rates. ${ }^{66} \mathrm{~A}$ huge debt is another incentive for migrant workers to accept terminating their official jobs

63 Luật Người Lao động đi Làm Việc ở Nước Ngoài Theo Hợp đồng [Law on Vietnamese Guest Workers], No. 72/2006/QH11 art. 27.1(b) (Nov. 29, 2006); Thông tu' Hướng dẫn chi tiết một số điều của Luật Người lao động Việt Nam đi làm việc ở nước ngoài theo hợp đồng và Nghị dịnh số 126/2007/NĐ-CP ngày or tháng 8 năm 2007 của Chính phủ quy định chi tiết và hướng dẫn một số diều của Luật Người lao động Việt Nam đi làm việc ở nước ngoài theo hợp đồng [Detailing a Number of Articles of the Law on Vietnamese Guest Workers and Governments Decree No. 126/2007/ND-CP Dated August 1, 2007, Detailing and Guiding a Number of Articles of the Law on Vietnamese Guest Workers], No. 21/2007/TT-BLDTBXH ch. 5 , art. 1 (Oct. 8, 2007).

64 Futaba Ishizuka, International Labour Migration in Vietnam and the Impact of Receiving Countries' Policies 6 (Inst. Developing Econs., Discussion Paper No. 414, 2013).

65 Dang, supra note 62, at 13 .

66 Angie Ngoc Tran \& Vicki Crinis, Migrant Labour and State Power: Vietnamese Workers in Malaysia and Vietnam, 13 Journal of Vietnamese Studies 27, 48 (2018). 
and/or overstaying their home country to do other illegal jobs because "they are under pressure to earn more than they can legally pay off their debt".67 This makes it difficult for the governments of Vietnam and receiving countries to protect migrant workers. With a desire to pay off outstanding debts and related expenses, some studies have shown that migrant workers have taken on other side jobs than they did in a formal job under a signed contract or even choose to unilaterally terminate the contract to do 'unrecognized, less empowered, less protected' jobs. ${ }^{68}$

\subsubsection{Awareness of Workers and Their Families on Legal Provisions on Migrant Worker's Rights Remains Limited}

Vietnamese workers abroad are mostly unskilled, mainly from rural areas, so they have limited foreign language, skills, and legal understanding. Therefore, their access to information on labor policies and laws, especially the labor market and employment, is incomplete or misleading, provided mainly by friends, family, and brokers.

In addition, when working abroad, a part of Vietnamese workers does not have a high sense of discipline, leading to violation of the law in the host country and the labor contract, thus facing legal issues such as contract termination or abuse. Moreover, some people have poor ability to integrate into the local community, leading to separate living and isolation. ${ }^{69}$ When their rights are violated, they often keep quiet and cannot speak up because they do not have foreign language skills, fear losing their jobs, or fear deportation (undocumented workers). According to data from researchers, only $4 \%$ of Vietnamese migrants try to fight for compensation for the abuse they experienced. ${ }^{70}$ In addition, due to illegal migration, victims hesitate to approach the host country's authorities to receive protection when they are abused. They are also hesitant to approach the Vietnamese diplomatic missions in that country for help. This mentality has created barriers for state agencies to resolve the issues and support them.

\footnotetext{
67 Dang, supra note 62, at 10.

68 Consular Dep't, Ministry of Foreign Affairs of Viet Nam, supra note 1, at 38.

69 Anthony Le Duc, The Role of Social Media in Community Building for Illegal Vietnamese Migrant Workers in Thailand, 10 Journal of Identity \& Migration Studies 4, 13, 15 (2016).

70 Phúc Quân, Cải thiện về pháp lý, giảm rủi ro cho lao động di cu' [Improving the Legal Framework, ReducingRisksforMigrant Workers],NHÂN DÂN(Nov.4, 2019), https://nhandan .com.vn/cung-suy-ngam/cai-thien-ve-phap-ly-giam-rui-ro-cho-lao-dong-di-cu-3759o2/.
} 
The Immigration Policies of Developed Countries Have Changed, Making It More Difficult for Vietnamese Workers to Find Jobs in These Countries

The political, economic, and social turmoil and the increase of crimes due to the "open door" policy have placed European countries on a reluctance to continue to accept migrant workers. Europe is no longer considered a peaceful land after a series of attacks were carried out in France, Germany, England etc., and the main culprits were immigrants. This situation deepens the disagreements between countries in the EU on the admission of immigrants. It is the driving force for European countries to reconsider their immigration policies to a more cautious and closed approach. This makes the path for Vietnamese migrant workers to legally move to the European countries or the United States more difficult, and the unofficial paths will have the opportunity to thrive when the demand of workers in these countries still exists. To overcome these difficulties, the Government needs to plan the necessary training policies to improve the workers' qualifications and skills and issue appropriate support policies to bring workers through the "narrow gate" to access the large labor markets legally. Of course, this is not easy and requires significant efforts from the State and the employees themselves.

\section{Some Recommendations to Effectively Ensure the Rights of Vietnamese Workers Abroad}

First of all, the Government should continue to review to improve policies and laws on migration towards the approach of direct access to the rights of migrant workers, and at the same time expanding legal access for migrant workers.

To improve the law on migrant workers, Vietnam needs to expand the protected groups to undocumented workers and supplement regulations related to the protection of female workers as they are the most vulnerable to abuse while working abroad. Vietnam needs to focus on legal approaches for migrant workers (especially female workers) regarding complaints mechanism when being abused to ensure fair and responsive measures. Besides reducing illegal labor migration, the Government also needs to issue policies to support workers, such as reducing labor export costs, supporting loans, etc.

In addition, the Government should pay attention and develop special policies for female workers when they go to work abroad and return home. Gender inequality and discrimination are important issues of human rights law. As for labor and employment, although there have been efforts to create equal rights for men and women to enjoy their right to work, however, due to 
different reasons, gender discrimination still occurs. Female workers working abroad also face many risks of abuse, especially sexual abuse, exploitation of the labor force, harassment. However, when returning home, women also have difficulty reintegrating and accessing services, especially job support services. Because social stereotypes and gender concepts are still heavy, many people do not share their families and relatives in raising children while working abroad.

Policies and regulations on migrant workers should be approached in the direction of best conditions and support for workers during the process before, during, and after the return of overseas workers. In particular, the reintegration policy after migration is very important to help workers feel secure in life. Unfavorable return conditions are factors that influence migrant's decisions to continue to work by overstaying their contracts or circular migrants. The majority of Vietnamese migrant workers, when returning home, often return to unskilled labor jobs, the jobs they did before migration and not related to the skills and knowledge that they acquired abroad due to inability to apply those skills and working style to working conditions in Vietnam or to start up a business. ${ }^{71}$ Therefore, they often fall into a confused, depressed mood and want to continue working abroad.

According to the IOM, the ILO, and the UN Women, to make the return of migrant workers meaningful, the State needs to consider implementing some solutions such as: ${ }^{72}$

(i) Standardizing documents to foster knowledge before going abroad to work;

(ii) Establish a specialized consular service for return and reintegration;

(iii) Establish a synchronized data collection system to capture all types of migration and return. Based on the collected data, it is possible to build profiles of returning migrants to develop programs to meet the needs of different target groups;

(iv) Improve social security;

(v) Develop a financial support program 'pay-on-return' in the form of sponsorships, loans, and other forms that can encourage return after contract termination without penalizing early returnees;

(vi) Develop skills development, career counselling, and personalized job placement programs, etc.

In addition, the State must continue to criminalize crimes related to illegal migration and build a stronger connection between the legal framework on labor and the criminal to prevent labor violations from developing into forced

71 Int'l Org. for Migration, Making the Return of Migrant Workers Work FOR VietNAM: AN ISSUE IN BRIEF 2 (2014).

72 Id. at $4-5$. 
labor and human trafficking. ${ }^{73}$ It should also expand legal access to migrant workers, especially female workers, who often face more difficulties than men at home and abroad. The ability of migrant workers to access complaint mechanisms for abuse during recruitment and employment is critical to ensuring fair and responsive remedies are in place. ${ }^{74}$

Secondly, consider joining the ICMW Convention and other relevant ILO Conventions while strengthening international cooperation on migration to create a legal basis to protect Vietnamese workers' legitimate rights and interests abroad.

As analyzed in the first section, the ICMW Convention has been seen as an important basis for the protection of the rights and interests of migrant workers in practice because many important rights which are stated in this Convention has not been mentioned in the previous international documents, or only mentioned in the documents that are not binding legal obligations to states ('soft' documents). ${ }^{75}$ The greatest contribution of this Convention is to recognize and take into account the diversity of the origin of migrant workers, which is reflected in the division of this group into two categories (with both documented and undocumented migrant workers) and give the necessary protection to their "family members". In addition, the Convention focuses on rights related to areas where migrant workers often have difficulties ('migrant in trouble' rights). Thus, from an international perspective, ICMW is becoming a comprehensive international document governing the rights of migrant workers and their family members, especially the rights of undocumented workers.

Although Vietnam is a major emigration country, it is also gradually becoming a market where foreign workers come to work. According to the Department of Employment (the Ministry of Labor, Invalids and Social Affairs), by the end of July 2019, 91,200 foreigners were working in Vietnam, of which 81,900 were subject to licensing. ${ }^{76}$ Therefore, Vietnam has played a role as a sending country but also a receiving country in international labor relations, although the reception is still quite modest. So, the ratification of the ICMW Convention and other relevant ILO's conventions will create an important foundation for

\footnotetext{
73 Nhật Anh, Quản trịtốt diculao động, thúc đẩy phát triển kinh tế [Goodmanagement of Labour Migration, Promoting Economic Development], NHÂN DÂN (July 29, 2019), https://nhandan .com.vn/tin-tuc-xa-hoi/quan-tri-tot-di-cu-lao-dong-thuc-day-phat-trien-kinh-te-366144/.

74 Press Release, Int'l Labor Org., ILO: Di cư lao động nên là sự lựa chọn an toàn [ILO: Labor Migration Should be a Safe Choice] (Oct. 29, 2019).

75 Int'L, Regional \& NAT'L L. \& PraC., supra note 29, at 51.

76 Press Release, Ministry of Labor, War Invalids \& Soc. Affairs, Lao động nước ngoài vào Việt Nam: Tăng sếp, giảm lao động kỹ thuật [Foreign Workers Entering Vietnam: Increase Boss, Reduce Technical Labor] (Aug. 23, 2019).
} 
both strengthening the legal foundation to ensure the rights of migrant workers and addressing violations of the rights of Vietnamese workers abroad, especially for undocumented workers.

However, as analyzed above, the ICMW is also facing the "reservations" of states because, like the relevant ILO conventions, this convention also only defines "one-way responsibility" for receiving states, which almost ignores the role of sending states. In addition, the extension of the obligation to protect even relatives of migrant workers when present in the territory of the receiving country is also a challenge for states to consider signing this Convention. In addition, similar to other international conventions, the Government of Vietnam probably carefully considered becoming a member to ensure its implementation of obligations arising from the Convention. For that reason, perhaps at this time, Vietnam is not a member of the ICMW, however, the spirit of this Convention, as well as the provisions on ensuring human rights in general and the rights of Vietnamese workers Vietnam in particular, is always respected, recognized and ensured in good-faith. Therefore, entering the ICMW may be on a suitable path for Vietnam soon.

In an effort to have international cooperation on migration, on March 20, 2020, the Prime Minister issued Decision No. 402/QĐ-TTg on promulgating a Plan for the implementation of the Global Agreement on legal, safe, and orderly migration of the United Nations. It is the first inter-governmental migration agreement aiming at strengthening cooperation in global migration governance, protecting the rights and interests of migrants for the sustainable development of the 2030 Agenda. However, to effectively implement this Agreement, it is necessary to outline a detailed plan and develop a monitoring mechanism to ensure the effectiveness and feasibility of the Strategy in practice.

Thirdly, promote activities of propaganda and dissemination of the law on migration to all strata of the people to raise awareness of people about their rights and at the same time raise awareness against trafficking crimes.

Propaganda and dissemination of the law should focus on the provisions of international laws and Vietnamese laws to prevent human trafficking and safe migration. Communication methods should be specific, clear, and easy to understand. In addition, for workers preparing for legal migration, there should be a program to disseminate laws and customs of the host country to raise awareness of compliance with the law and a respectful attitude towards the communities where they work.

In addition, it is necessary to widely propagate among all strata of society about the Governmental policies to support migrant workers returning home to encourage, motivate and create confidence for them to start a business. In 
addition, the Government also needs to develop a set of guidance documents on migration policies and laws for workers; provide legal advice, address, and support them in the whole process before, during, and after returning from abroad.

Significantly, the migrant workers themselves and their families need to change their mindset, to proactively access information on labor and employment on official channels of State instead of passively receive unofficial information provided by others. Workers need to equip themselves with basic knowledge about labor export as well as State policies and laws on labor export to ensure their legitimate interests and at the same time protect themselves in necessary cases.

Fourthly, improve the capacities and responsibilities of state management agencies on migrant workers; develop a mechanism of cooperation and information sharing among state agencies to manage better activities of sending Vietnamese workers to work abroad, promptly protect, provide relief, and evacuate workers when needed.

Although Vietnamese representative missions in foreign countries are responsible for managing migrant workers, this action has not been effective. These agencies should review applicable international migration policies and regulations and toward optimizing migration procedures to reduce costs, better serve the legitimate international migration needs of individuals, and at the same time create better conditions for immigration management through the electricity database. For example, it can be easily disaggregated according to basic criteria such as age, sex, destination, and migration purpose.

In addition, these agencies also need to strengthen the inspection and examination of the activities of labor export service providers to suspend ineligible enterprises or handle violations in a timely manner. Besides, it is necessary to properly advise the Government in the formulation or amendment of regulations that are not reasonable for labor export activities; proposing to create a focal point agency in building international migration databases of different types; periodically build migration profiles for management and development. ${ }^{77}$

Finally, promote cooperation between sending, transit, and receiving states to strengthen and secure legitimate migration options, especially for female workers, to ensure adequate employment needs. TION PROFILE 2016, at 84 (2017). 
The sending country will face many difficulties accessing the activities and policies for migrant workers of the receiving country if the parties do not have close cooperation activities. It is because of national sovereignty. According to Article 2 of the United Nations Charter, states have absolute and independent sovereignty in international relations. States are obliged to respect the independent sovereignty of another country. Therefore, the act of intentionally carrying out activities without the consent of the receiving state in their territory will be considered a violation of national territorial sovereignty. Therefore, the most legitimate way for countries is to increase international cooperation activities to create a two-way mechanism for both sending and receiving countries.

While waiting for a further step forward in joining international universal tools for migrant workers' rights, to ensure the protection of workers' human rights of Vietnamese migrants in the receiving countries, it is recommended to continue to promote the signing of bilateral cooperation agreements and measures to exchange immigration information with other countries to limit illegal migrants and human trafficking. ${ }^{78}$ For countries that have not signed cooperation agreements, Vietnam still applies the principle of reciprocity with its commitment to give each other's migrant workers proper and fair treatment. Vietnam has signed international agreements related to labor export with some countries such as Japan, Korea, Germany, and some of the ASEAN countries. The labor market in which Vietnamese workers come to work is more and more open, not only at some of the above markets. Therefore, in the coming days, Vietnam needs to continue negotiating with other receiving countries to sign cooperation agreements to create a legal basis for ensuring the rights and interests of Vietnamese workers working abroad and vice versa.

The sending of workers abroad is a major policy of the Party and the State of Vietnam. The trend of international integration is in line with the current international migration tendency, based on equality, mutual benefit, and the interests of the nation and the people. However, the gaps and limitations of legal provisions related to illegal migration, or ineffectiveness in policies to support the reintegration of migrant workers, etc., are becoming a significant barrier for Vietnam in ensuring the migrant worker's rights in practice.

78 Dau Tuan Nam, Managing Migration Crisis From the Perspective of International Cooperation for Vietnam, 9 Political Theory Journal 115 (2017). 
Migrant workers, whether legal or illegal, documented or undocumented, are themselves human beings and citizens of the country. Therefore, in addition to recognizing rights as a fundamental human being, there must be more specific provisions for migrants to limit any violation of rights against them in the migration process.

With the view that no one is left behind, Vietnam is also actively reviewing the policies and laws on migrant workers. The National Assembly of Vietnam has approved the Law of Vietnamese worker working abroad under the contract 2006 with new contents, that are more in line with the real situation of Vietnam. This shows the efforts of the Vietnamese Government in building a legal basis for protecting the rights and interests of Vietnamese workers working abroad. As a new generation of trade agreements with high requirements for labor and migrant workers, this Law becomes one of the important legal instruments for Vietnam to materialize the international commitments. With these efforts, it is possible to expect a complete, transparent, and unified legal framework on migration soon. 